\title{
MENINGKATKAN PEMAHAMAN KONSEP PESERTA DIDIK TENTANGPENINGGALAN SEJARAH HINDU-BUDHA ISLAM PADA PEMBELAJARAN IPS MELALUI MODEL PEMBELAJARAN MAKE-A MATCH DI SDN KARANG MULYA II
}

\author{
Aden Muhammad Kosambi, M.Pd ${ }^{1}$ \\ Noermalita Ika Sapoetri, S.Pd ${ }^{2}$ \\ Dosen STKIP Subang ${ }^{1}$ \\ Guru SD Gita Lembang ${ }^{2}$ \\ noermalita_ika27@gmail.com
}

\begin{abstract}
IPS Learning in school is still not as expected. It can be seen from the lack of understanding the concept of students in social studies learning. Results of the assessment implementation of learning in cycle 1 scored 3.3 with either category, and the second cycle increased with the acquisition value of 3.46 with both categories. While in the third cycle assessment learning implementation to achieve the target indicators of success with the acquisition value of 3.7 with a very good category. The results of the cognitive understanding of the concept of the product $(P 1)$ in the first cycle of the data obtained learners who pass as many as 10 Orang learners with a percentage of $43.47 \%$. In the second cycle there was an increase of learners who pass to 15 students with a percentage of $65.21 \%$. In the third cycle increased to reach the indicators of success with learners who completed 20 people learners (86.9\%). The result of understanding the concept of cognitive processes (P2) in the first cycle of the data obtained learners who completed a total of 12 Orang learners with a percentage of $52.17 \%$. In the second cycle there was an increase of learners who pass to 16 students with a percentage of $69.56 \%$. In the third cycle increased to reach the indicators of success with learners who completed 20 people learners (86.9\%). The result of understanding the concept of psychomotor (P3) in cycle 1 earn a percentage of $60.52 \%$. In the second cycle obtain an increase in the percentage of $78.26 \%$. In the third cycle increased to reach the indicators of success with the acquisition of a percentage of $85.21 \%$.
\end{abstract}

Keywords: Concept Training, Social Learning, Learning Model Make-A Match.

\section{ABSTRAK}

Pembelajaran IPS di sekolah masih belum seperti yang diharapkan. Hal ini dapat terlihat dari rendahnya pemahaman konsep peserta didik pada pembelajaran IPS. Hasil penilaian pelaksanaan pembelajaran pada siklus 1 memperoleh nilai 3,3 dengan kategori baik, dan pada siklus 2 terjadi peningkatan dengan perolehan nilai 3,46 dengan kategori baik. Sedangkan pada siklus 3 penilaian pelaksanaan pembelajaran mencapai target indikator keberhasilan dengan perolehan nilai 3,7 dengan kategori sangat baik. Hasil pemahaman konsep kognitif produk (P1) pada siklus 1 memperoleh data peserta didik yang 


\section{Didaktik : J urnal Pendidikan Guru Sekolah Dasar, ISSN : 2477-5673 \\ Sekolah Tinggi Keguruan dan IImu Pendidikan Subang Volume I Nomor 2, J uli 2016}

tuntas sebanyak 10 Orang peserta didik dengan presentase 43,47\%. Pada siklus 2 terjadi peningkatan peserta didik yang tuntas menjadi 15 orang peserta didik dengan presentase $65,21 \%$. Pada siklus 3 terjadi peningkatan yang mencapai indikator keberhasilan dengan peserta didik yang tuntas ada 20 orang peserta didik (86,9\%). Hasil pemahaman konsep kognitif proses (P2) pada siklus 1 memperoleh data peserta didik yang tuntas sebanyak 12 Orang peserta didik dengan presentase 52,17\%. Pada siklus 2 terjadi peningkatan peserta didik yang tuntas menjadi 16 orang peserta didik dengan presentase $69,56 \%$. Pada siklus 3 terjadi peningkatan yang mencapai indikator keberhasilan dengan peserta didik yang tuntas ada 20 orang peserta didik (86,9\%). Hasil pemahaman konsep psikomotor (P3) pada siklus 1 memperoleh presentase 60,52\%. Pada siklus 2 terjadi peningkatan memperoleh presentase 78,26\%. Pada siklus 3 terjadi peningkatan yang mencapai indikator keberhasilan dengan perolehan presentase $85,21 \%$.

Kata Kunci : Pemahaman Konsep, Pembelajaran IPS, Model Pembelajaran make-A Match.

\section{PENDAHULUAN}

Guru diibaratkan patriot dalam peperangan, keberhasilan perang tergantung patriot sebagai barisan terdepan dalam menghadapi musuh, dalam proses pembelajaran guru adalah faktor penentu keberhasilan belajar, disamping alat, fasilitas, sarana dan kemampuan peserta didik itu sendiri. Menyangkut faktor guru, banyak keterampilan yang harus dimiliki dan dikuasai dengan baik, agar proses pembelajaran menjadi bermakna dan selalu relevan dengan tujuan dan bahan ajaranya. Fungsi dan peran guru sebagai perencana, pelaksana dan penilai dalam proses pembelajaran.

Tugas guru adalah menciptakan supaya tercipta aktvitas belajar. Belajar dapat membangun pemahaman, pengertian, dan keterampilan yang baru berdasarkan interaksi dengan lingkungan menuju perubahan ke arah yang lebih baik, fungsi guru adalah memberdayakan seluruh pikiran, perasaan, sikap, potensi yang dimiliki peserta didik.
Dalam pembelajaran guru dituntut kreatif dalam mengarahkan kegiatan belajar peserta didik agar mencapai keberhasilan belajar (kinerja akademik) sebagaimana yang telah diterapkan dalam sasaran kegiatan proses belajar mengajar. Dengan demikian, semakin jelaslah bahwa peranan guru dalam dunia pendidikan modern seperti sekarang ini semakin meningkat dari sekedar pengajar menjadi direktur belajar.Konsekuensinya tugas dan tanggung jawab guru pun menjadi lebih kompleks dan berat pula.

Untuk melaksanakan kewajiban tersebut, guru harus memiliki kemampuan memilih model pembelajaran yang efektif dan menarik bagi peserta didik sehingga terjadi perubahan kearah yang lebih baik. Perubahan sebagai hasil dari proses belajar dapat ditunjukan dalam berbagai bentuk seperti perubahan pengetahuan, pemahaman, sikap, tingkah laku, keterampilan, kecakapan, dan kemampuannya serta perubahanperubahan aspek lain yang ada pada 


\section{Didaktik : J urnal Pendidikan Guru Sekolah Dasar, ISSN : 2477-5673 \\ Sekolah Tinggi Keguruan dan IImu Pendidikan Subang \\ Volume I Nomor 2, J uli 2016}

diri individu yang sedang belajar. (Sudjana, 1989) mengatakan bahwa Guru menempati kedudukan sentral, sebab peranannya sangat menentukan. la harus mampu menterjemahkan dan menjabarkan nilai-nilai yang terdapat dalam kurikulum, kemudian mentranspormasikan nilai-nilai tersebut kepada peserta didik melalui proses pembelajaran di sekolah.

Penggunaan suatu model pembelajaran dalam pelaksanaan pembelajaran membantu kelancaran efektifitas dan efisiensi pencapaian tujuan, sehingga pembelajaran menjadi bermakna.Proses pembelajaran memerlukan suatu model pembelajaran yang tepat dengan memperhatikan tingkat kemampuan peserta didik, dapat memfasilitasi potensi peserta didik , peserta didik diarahkan untuk aktif secara mental, fisik maupun sosial.

Menurut (Rina Laela Sukmasari, 2004) pemberian informasi kepada peserta didik masih dipandang penting, namun perlu diselingi dengan berbagai model pembelajaran yang dapat membuat suasana pembelajaran lebih hidup dan menyenangkan bagi peserta didik maupun guru.

Menurut (Agus Suprijono,2009) model pembelajaran dapat didefinisiskan sebagai kerangka konseptual yang melukiskan prosedur sistematis dalam mengorganisasikan pengalaman belajar untuk mencapai tujuan belajar, sedangkan menurut (Miftahul huda, 2013) strategi make A match saat ini menjadi salah satu strategi penting dalam ruang kelas.

Dapat disimpulkan bahwa model pembelajaran merupakan strategi belajarmengajaryang melukiskan prosedur sistematis dalam mengorganisasikan pengalaman belajar untuk mencapai tujuan belajar.Pembelajaran IPS di sekolah dasar dapat dilakukan melalui beberapa model diantaranya model pembelajaran Make A-Match.

IPS sebagai salah satu bidang studi yang memiliki tujuan membekali peserta didik untuk mengembangkan penalarannya di samping aspek nilai dan moral, maka pembelajaran akan lebih bermakna jika peserta didik terlibat secara aktif, diantaranya dengan menggunakan berbagai model dan teknik yang sesuai dengan pokok bahasan. Hal ini dimaksudkan agar pembelajaran menjadi bermakna bagi peserta didik.

Mata pelajaran IPS disusun secara sistematis,komprehensif,dan terpadu dalam proses pembelajaran menuju kedewasaan dan keberhasilan dalam kehidupan di masyarakat. Dengan model pembelajaran diharapkan peserta didik akan memperoleh pemahaman yang lebih luas dan mendalam pada bidang ilmu yang berkaitan.

Menurut Ruseffendi (Juwita, 2010) pemahaman adalah kemampuan menangkap pengertianpengertian seperti mampu mengungkapkan suatu meteri yang diajarkan ke dalam bentuk yang dapat dipahami, mampu memberikan interpretasi dan mampu mengklasifikasikannya.

Sedangkan konsep menurut (Syaiful Sagala,2003) yang menyatakan bahwa konsep merupakan buah pemikiran seseorang atau sekelompok orang yang dinyatakan dalam definisi sehingga melahirkan produk pengetahuan meliputi prinsip, hukum, dan teori.

Dari pengertian di atas, dapat disimpulkan bahwa pemahaman konsep adalah kemampuan mengungkapkan materi yang 


\section{Didaktik : J urnal Pendidikan Guru Sekolah Dasar, ISSN : 2477-5673 \\ Sekolah Tinggi Keguruan dan IImu Pendidikan Subang \\ Volume I Nomor 2, J uli 2016}

diajarkan ke dalam bentuk yang dipahami yang dinyatakan dalam definisi sehingga melahirkan produk pengetahuan meliputi prinsip, hukum, dan teori.

Meningkatkan pemahaman peserta didik merupakan objek yang harus dibina dan dikembangkan terus menerus secara menyeluruh yang meliputi aspek pengetahuan, keterampilan, sikap, dan nilai-nilai. Pengembangan aspek- aspek tersebut dilakukan untuk meningkatkan dan mengembangkan kecakapan hidup (life skill) melalui seperangkat kompetensi .Peningkatan kompetensi tersebut membutuhkan berpikir sistematik, logis, dan kritis.

Pendidikan IImu Pengetahuan Sosial (IPS) sebagai salah satu program pendidikan untuk mempersiapkan manusia Indonesia seutuhnya yang mampu relevan dengan kehidupan masyarakat modern. Menurut (Jaka Permana, 2012) IPS adalah bidang studi yang mempelajari, menelaah, menganalisis gejala dan masalah social di masyarakat dengan meninjau berbagai aspek kehidupan secara terpadu.

Berdasarkan latar belakang di
atas, peneliti bermaksud
mengadakan Penelitian Tindakan
Kelas, dengan judul "Meningkatkan
Pemahaman Konsep Peserta Didik
tentang Peninggalan Sejarah
Hindu-Budha IslamPada
Pembelajaran IPS Melalui Model
Pembelajaran Make-A Match".
Penelitian Tindakan Kelas ini
dilakukan di kelas V semester 1 SD
Negeri Surialaya Kecamatan
Pagerageung
Tasikmalaya.

DASAR PEMIKIRAN

\section{Pengertian IImu Pengetahuan Sosial}

Ilmu Pengetahuan Sosial (IPS) merupakan salah satu mata pelajaran yang diajarkan di Sekolah Dasar, juga merupakan salah satu mata pelajaran yang memadukan konsepkonsep dasar dari berbagai ilmu sosial yang disusun melalui pendekatan pendidikan supaya bermakna bagi siswa dalam kehidupannya. Secara mendasar, pembelajaran IPS berkenaan dengan kehidupan manusia yang melibatkan segala tingkah laku dan kebutuhannya. IPS berkenaan dengan cara manusia memenuhi kebutuhannya, baik kebutuhan untuk memenuhi materi, budaya, dan kejiwaannya, memanfaatkan sumber daya yang ada dipermukaan bumi, mengatur kesejahteraan dan pemerintahannya maupun kebutuhan lainnya dalam rangka mempertahankan kehidupan masyarakat manusia. Singktnnya, IPS mempelajari, menelaah, dan mengkaji sistem kehidupan manusia di permukaan bumi ini dalam konteks sosialnya atau manusia sebagai anggota masyarakat.

Pendidikan IImu Pengetahuan Sosial yang sering kali disingkat Pendidikan IPS atau PIPS Menurut (Sapriya, 2009), merupakan dua istilah yang sering diucapkan atau dituliskan dalam berbagai karya akademik secara tumpang tindih (overlapping). Kekeliruan ucapan ataupun tulisan tidak dapat sepenuhnya kesalahan pengucap atau penulis melainkan disebabkan oleh kurangnya sosialisasi sehingga menimbulkan perbedaan persepsi. Faktor lain dimungkinkan karena kurangnya forum akademik yang membahas dan memasyarakatkan 


\section{Didaktik : J urnal Pendidikan Guru Sekolah Dasar, ISSN : 2477-5673 \\ Sekolah Tinggi Keguruan dan IImu Pendidikan Subang \\ Volume I Nomor 2, J uli 2016}

istilah atau nomenklatur hasil kesepakatan komunitas akademik.

Menurut Somantri (Sapriya, 2009) menyatakan "IPS adalah penyederhanaan atau disiplin ilmu ilmu sosial humaniora serta kegiatan dasar manusia yang diorganisasikan dan disajikan secara ilmiah dan pedagogis/psikologis untuk tujuan pendidikan".

Berdasarkan

beberapa pendapat di atas dapat ditarik kesimpulan bahwa IImu Pengetahuan Sosial wajib diajarkan kepada siswa siswi Sekolah Dasar karena IPS salah satu mata pelajaran yang memadukan konsep-konsep dasar dari berbagai ilmu sosial yang disusun melalui pendekatan pendidikan supaya bermakna bagi siswa dalam kehidupannya.

\section{Pembelajaran Kooperatif tipe STAD}

Menurut Bruce Joyce, Marsha Weil, dan Emily Calhoun (2009) mengungkapkan bahwa :

Model pembelajaran kooperatif Example Non Example atau juga biasa disebut Example Non Example merupakan tipe pembelajaran yang menggunakan gambar sebagai media pembelajaran. Penggunaan media gambar ini disusun dan dirancang agar anak dapat menganalisis gambar tersebut menjadi sebuah bentuk diskripsi singkat mengenai apa yang ada didalam gambar. Penggunaan model Pembelajaran kooperatif tipe Example Non Example ini lebih menekankan pada konteks analisis siswa. Biasa yang lebih dominan digunakan di kelas tinggi, namun dapat juga digunakan di kelas rendah dengan menenkankan aspek psikoligis dan tingkat perkembangan siswa kelas rendah seperti; kemampuan berbahasa tulis dan lisan, kemampuan analisis ringan, dan kemampuan berinteraksi dengan siswa lainnya. Tipe Example Non Example menggunakan gambar dapat melalui OHP, proyektor, atau media yang paling sederhana yaitu poster. Gambar yang kita gunakan haruslah jelas dan kelihatan dari jarak jauh, sehingga anak yang berada di belakang dapat juga melihat dengan jelas.

Berdasarkan pengertian di atas dapat disimpulkan bahwa Model Pembelajaran Kooperatif (Cooperative Learning) Tipe Examples Non Examples merupakan strategi pembelajaran yang menggunakan gambar sebagi media untuk menyampaika materi pelajaran. Media gambar tersebut merupakan contoh-contoh untuk mendorong siswa lebih bisa memahami materi dan bisa memecahkan masalah melalui menanalisis sebuah gambar. Penggunaan gambar ini disusun dan dirancang agar anak dapat menganalisis gambar tersebut menjadi sebuah bentuk diskripsi singkat mengenai apa yang ada didalamnya. Example Non Example salah satu teknik yang dapat digunakan oleh guru dalam proses pembelajaran. Teknik ini merupakan contoh pembelajaran efektif yang dikeluarkan oleh Kementrian Pendididkan dan Kebudayaan.

\section{Pemahaman Konsep}

Menurut Bloom (Vestari, 2009) "Pemahaman Konsep adalah kemampuan mengungkapkan pengertian-pengertian seperti mampu mengungkapkan suatu materi yang disajikan kedalam bentuk yang lebih dipahami, mampu memberikan interprestasi dan mampu mengaplikasinya".

Berdasarkan Pengertian

Pemahaman dan Konsep seperti di atas, maka dapat disimpulkan 


\section{Didaktik : J urnal Pendidikan Guru Sekolah Dasar, ISSN : 2477-5673 Sekolah Tinggi Keguruan dan Ilmu Pendidikan Subang Volume I Nomor 2, J uli 2016}

Pemahaman konsep adalah kemampuan mengungkapkan suatu materi yang disajikan dalam bentuk yang lebih bisa dipahami dalam bentuk konkrit atau abstrak, luas atau sempit, dan satu atau frase.

\section{METODE PENELITIAN}

Desain penelitian ini menggunakan model penelitian tindakan kelas yang terdiri dari 2 siklus. Setiap siklusnya meliputi tahapan perencanaan, pelaksanaan tindakan, observasi dan refleksi.

\section{HASIL PENELITIAN}

Berdasarkan kegiatan pelaksanaan siklus I pada siklus I hasil belajar siswa dalam proses pembelajaran pada kegiatan pretes mencapai nilai rata-rata 65,6 atau memiliki kategori sedang dan hasil belajar pada kegiatan postes mencapai nilai rata-rata 65,83 atau memiliki kategori sedang, dari 36 siswa SDN Karang Mulya II siswa yang sudah mencapai Kriteria Ketuntasan Minimal adalah sebanyak 12 siswa sebesar 33,3\%, dan siswa yang belum mencapai Kriteria Ketuntasan Minimal adalah sebanyak 24 siswa sebesar $66,7 \%$.

Berdasarkan hasil analisis lembar observasi nilai Menirukan Pengucapan Bahasa Daerah Dari Suku Bangsa Lain pada penelitian siklus I diketahui bahwa siswa yang masuk dalam kategori BAIK sebanyak 8 orang atau $22,2 \%$, siswa yang mendapat nilai kategori CUKUP sebanyak 22 orang atau $61,1 \%$, dan siswa yang mendapat nilai kategori KURANG adalah 6 orang atau $16,7 \%$. Oleh karena itu, peneliti merasa perlu untuk mengadakan penelitian siklus II untuk memperbaiki segala kekurangan, baik dari proses maupun hasil yang terjadi pada siklus I.
Berdasarkan hasil analisis lembar observasi nilai menunjukkan sikap persahabatan yang baik terhadap suku bangsa lain pada penelitian siklus I diketahui bahwa siswa yang masuk dalam kategori BAIK sebanyak 10 orang atau $27,8 \%$, siswa yang mendapat nilai kategori CUKUP sebanyak 19 orang atau $52,8 \%$, dan siswa yang mendapat nilai kategori KURANG adalah 7 orang atau $19,4 \%$. Oleh karena itu, peneliti merasa perlu untuk mengadakan penelitian siklus II untuk memperbaiki segala kekurangan, baik dari proses maupun hasil yang terjadi pada siklus I.

Berdasarkan hasil analisis terhadap lembar observasi pemahaman konsep siswa maka peneliti menyimpulkan bahwa pencapaian pemahaman konsep siswa siswa masih kurang karena siswa yang mendapat nilai kategori BAIK sebanyak 11 orang sebesar $30,6 \%$, siswa yang mendapat nilai kategori SEDANG sebanak 19 orang atau sebanyak $52,8 \%$, dan siswa yang mendapat kategori KURANG sebanyak 4 orang atau sebanyak $11,1 \%$. Oleh karena itu, peneliti merasa perlu untuk mengadakan penelitian siklus II untuk memperbaiki segala kekurangan, baik proses maupun hasil yang terjadi pada siklus I.

Pada siklus II, Berdasarkan hasil analisis data yang diperoleh dari hasil diskusi yang dilakukan peneliti dengan pengamat / observer mnegenai implementasi guru dalam proses kegiatan belajar mengajar mempunyai kategori Sangat baik dengan nilai persentase $100 \%$. Dengan kata lain ,semua komponen sudah muncul dan sesuai dengan indikator keberhasilan pada Bab III.

Pada siklus II hasil belajar siswa dalam proses pembelajaran pada 


\section{Didaktik : J urnal Pendidikan Guru Sekolah Dasar, ISSN : 2477-5673 \\ Sekolah Tinggi Keguruan dan IImu Pendidikan Subang Volume I Nomor 2, J uli 2016}

kegiatan pre-test mencapai nilai ratarata 75 atau memiliki kategori Baik dan hasil belajar pada kegiatan postest mencapai nilai rata-rata 76,7 atau memiliki kategori Baik . Dari 36 siswa SDN Karang Mulya II siswa yang sudah mencapai Kriteria Ketuntasan Minimal adalah sebanyak 32 siswa sebesar 88,9 \%, dengan Kriteria Ketuntasan Minimal (KKM) yang telah ditetapkan, yaitu 70. hasil belajar siswa sudah memenuhi indikator keberhasilan yang telah ditetapkan pada Bab III yaitu pada aspek ketuntasan belajar dengan persentase mencapai $>80 \%$.

Berdasarkan hasil analisis lembar observasi nilai Menirukan Pengucapan Bahasa Daerah Dari Suku Bangsa Lain pada penelitian siklus II diketahui bahwa siswa yang masuk dalam kategori BAIK sebanyak 32 orang atau 88,9\%, siswa yang mendapat nilai kategori CUKUP sebanyak 4 orang atau $11,1 \%$, dan tidak ada siswa yang mendapat nilai kategori KURANG. Maka dari itu, pelaksanaan tindakan siklus II peneliti menyimpulkan bahwa peningkatan nilai menirukan pengucapan bahasa daerah dari suku bangsa lain siswa sudah tercapai BAIK.

Berdasarkan hasil analisis lembar observasi nilai menunjukkan sikap persahabatan yang baik terhadap suku bangsa lain pada penelitian siklus II diketahui bahwa siswa yang masuk dalam kategori BAIK sebanyak 33 orang atau 91,7\%, siswa yang mendapat nilai kategori CUKUP sebanyak 3 orang atau $8,3 \%$, dan tidak ada siswa yang mendapat nilai kategori KURANG. Maka dari itu, pelaksanaan tindakan siklus II peneliti menyimpulkan bahwa peningkatan nilai lembar observasi menunjukan sikap persahabatan yang baik terhadap suku bangsa lain siswa sudah tercapai BAIK.

Berdasarkan hasil analisis lembar observasi nilai menunjukkan sikap persahabatan yang baik terhadap suku bangsa lain pada penelitian siklus II diketahui bahwa siswa yang masuk dalam kategori BAIK sebanyak 30 orang atau $83,3 \%$, siswa yang mendapat nilai kategori CUKUP sebanyak 6 orang atau $16,7 \%$, dan tidak ada siswa yang mendapat nilai kategori KURANG. Maka dari itu, pelaksanaan tindakan siklus II peniliti menyimpulkan bahwa peningkatan nilai lembar observasi menyanyi lagu daerah suku bangsa lain siswa sudah tercapai BAIK.

Berdasarkan hasil analisis terhadap lembar observasi pemahaman konsep siklus II siswa maka peneliti menyimpulkan bahwa pencapaian pemahaman konsep siswa siswa sudah Baik, karena siswa yang mendapat nilai kategori BAIK sebanyak 32 orang sebesar $88,9 \%$, siswa yang mendapat nilai kategori SEDANG sebanyak 4 orang atau sebanyak $11,1 \%$, dan tidak ada siswa yang mendapat kategori KURANG.

Berdasarkan hasil analisis dan angket respon siswa terhadap proses pembelajaran menggunakan model Cooperative Learning tipe Examples non examples pada umumnya sangat disukai oleh seluruh siswa. Hal tersebut diketahui dari hasil persentase dengan pencapaian nilai sebesar $80 \%$ siswa memberikan pernyataan pada pilihan YA dan memiliki kategori baik sesuai dengan target yang diharapkan.

Berdasarkan hasil dari penelitian siklus II yang dibandingkan dengan indikator keberhasilan penelitian tindakan kelas yang telah ditentukan, peneliti merasa bahwa penelitian siklus II telah berhasil 


\section{Didaktik : J urnal Pendidikan Guru Sekolah Dasar, ISSN : 2477-5673 Sekolah Tinggi Keguruan dan Ilmu Pendidikan Subang Volume I Nomor 2, J uli 2016}

dengan kualitas yang baik. Peningkatan dan ketercapaian target penelitian telah terjadi pada proses dan hasil pembelajaran materi keragaman suku bangsa dan budaya di Indonesia dengan menggunakan model Cooperative Learning tipe Examples non examples. Oleh karena itu, peneliti mencukupkan pelaksanaan penelitian tindakan kelas ini sampai dengan siklus II.

\section{PEMBAHASAN}

Agar model cooperative learning tipe Examples non Examples dapat diimplementasikan dalam proses pembelajaran, guru harus membuat rancangan terlebih dahulu yang berbasis strategi pembejaran dan model pembelajran yang digunakan. pelaksanaan pembelajaran melalui penggunaan model pembelajaran Cooperative Learning tipe Examples non examples dilaksanakan sebanyak dua siklus. Pembelajaran kooperatif adalah suatu sistem yang didasarkan pada alasan bahwa manusia sebagai makhluk individu yang berbeda satu sama lain sehingga konsekuensi logisnya manusia harus menjadi makhluk sosial, makhluk yang berinteraksi dengan sesama (Nurhadi 2003). Dengan penerapan model cooperative learning tipe examples non examples dalam kegiatan pembelajaran siswa tidak lagi hanya mentransformasikan informasi yang didapatnya kedalam catatan linear berupa barisan huruf-huruf yang tersusun secara teratur dalam barisbaris halaman buku, tetapi siswa dapat membuat catatan yang menarik,bebas berkreasi dalam menyusun sebuah catatan yaitu dengan bantuan berbagai simbol, gambar, kata kunci dan berbagai warna yang membuat siswa tertarik untuk membaca, catatan mini dibuat dengan cepat dan mengakibatkan kualitas visual yang baik sehingga mudah diingat Russel (lisnawati, 2006).

Pelaksanaan pembelajaran merupakan implementasi dari Rencana Pelaksanaan Pembelajaran (RPP). Pelaksanaan pembelajaran meliputi kegiatan pendahuluan,kegiatan inti dan kegiatan pentup menurut (Wina Sanjaya, 2009)"Pelaksanaan tindakan adalah perlakuan yang dilaksanakan guru berdasarkan perencanaan yang telah disusun ". Pada tahap ini serangkaian rancangan, strategi, skenario pembelajaran yang akan diterapkan. Implementasi pembelajaran yang dilakukan peneliti dari siklus I sampai Il menggunakan model Cooperative Learning tipe examples non examples.

Cooperative Learning adalah suatu sistem yang didasarkan pada alas an bahwa manusia sebagai makhluk individu yang berbeda satu sama lain sehingga konsekuensi logisnya manusia harus menjadi makhluk sosial, makhluk yang berinteraksi dengan sesama (Nurhadi 2003). Dengan penerapan model cooperative learning tipe examples non examples dalam kegiatan pembelajaran siswa tidak lagi hanya mentransformasikan informasi yang didapatnya kedalam catatan linear berupa barisan huruf-huruf yang tersusun secara teratur dalam barisbaris halaman buku, tetapi siswa dapat membuat catatan yang menarik,bebas berkreasi dalam menyusun sebuah catatan yaitu dengan bantuan berbagai simbol, gambar, kata kunci dan berbagai warna yang membuat siswa tertarik untuk membaca, catatan inni dibuat dengan cepat dan mengakibatkan kualitas visual yang baik sehingga 


\section{Didaktik : J urnal Pendidikan Guru Sekolah Dasar, ISSN : 2477-5673 \\ Sekolah Tinggi Keguruan dan Ilmu Pendidikan Subang Volume I Nomor 2, J uli 2016}

mudah diingat Russel (lisnawati,2006).

Pelaksanaan pembelajaran merupakan implementasi dari RPP yang telah disusun. Pelaksanaan pembelajaran pada umumnya meliputi kegiatan pendahuluan, kegiatan inti dan kegiatan penutup. Pada tahap ini serangkaian strategi dan skenario pembelajaran yang telah disusun berusaha untuk diimplementasikan oleh peneliti dengan sebaik mungkin agar tujuan yang diinginkan dapat tercapai secara cepat dan tepat. Implementasi pembelajaran yang dilakukan peneliti dari siklus I sampai dengan siklus II menggunakan model cooperative learning tipe examples non examples. Model pembelajaran

ini mengoptimalkan siswa untuk terlibat secara aktif dalam diskusi kelompok ehingga terjalin interaksi antar siswa dan memudahkan siswa untuk menemukan sendiri inti dari materi yang dipelajari.

Untuk mengetahui hasil pencapain dan peningkatan pemahaman konsep siswa, dalam hal ini adalah keterampilan siswa dalam aspek pemahaman konsep siwa selama proses pembelajaran, peneliti melakukan penilaian berdasarkan hasil belajar siswa (aspek kognitif) dalam bentuk soal pos-test, dan nilai lembar observasi (aspek psikomotor afektif).

Berdasarkan observasi awal terhadap proses pembelajaran IPS materi keragaman suku bangsa dan budaya di Indonesia di kelas V SDN Karang Mulya II, ditemukan fakta tentang kurangnya tingkat pemahaman konsep siswa. Rendahnya pemahaman konsep siswa pada pembelajaran salah satunya disebabkan oleh faktor guru yang menggunakan metode konvensional, proses pembelajaran hanya terjadi satu arah dari guru ke siswa, sehingga siswa hanya pasif mendengarkan penjelasan dari guru serta siswa tidak memiliki kesempatan untuk mencari dan menemukan konsepnya sendiri terhadap materi pelajaran.

Berawal dari permasalahan di atas, maka penelitian terdorong untuk meningkatkan pemahaman konsep siswa, dalam hal ini adalah pemahaman konsep siswa dalam proses pembelajaran.

Berdasarkan analisis data nilai pos-test siswa sebelum pelaksanaan tindakan sampai dengan siklus II, diketahui bahwa perkembangan dari aspek kognitif siswa terkait model cooperative learning tipe examples non examples pada materi keragaman suku bangsa dan budaya di Indonesia menunjukan peningkatan secara signifikan. Dari 36 siswa yang ada, pada siklus I nilai rata-rata siswanya adalah 65,83, jumlah siswa yang mencapai KKM sebanyak 12 orang (33,3\%) dan jumlah siswa yang masuk kategori BAIK (rentang nilai 70-100) sebanyak 12 orang $(33,3 \%)$. Pada siklus II, nilai rata-rata siswanya mengalami peningkatan menjadi 76,7 , jumlah siswa yang mencapai KKM meningkat sebanyak 32 orang $(88,9 \%)$ dan jumlah siswa yang masuk kategori BAIK (rentang nilai 70-100) sebanyak 32 orang (88,9\%).

Pada siklus I, siswa yang belum mencapai KKM sebanyak 20 orang $(55,6 \%)$. Sedangkan siklus II siswa yang belum mencapai KKM sebanyak 4 orang $(11,1 \%)$.

\section{KESIMPULAN}

Berdasarkan hasil analisis data pembehasan hasil analisis, dapat disimpulkan bahwa penggunaan model pembelajaran Cooperative Learning tipe Examples Non 
Examples dapat meningkatkan pemahaman konsep siswa pada pembelajaran IPS kelas $\mathrm{V}$ di SDN Karang Mulya II Kota Bandung Peningkatkan pemahaman konsep siswa pada pembelajaran IPS kelas V pada materi "Keragaman Suku Bangsa dan Budaya di indonesia" di SDN Karang Mulya II Kota Bandung. Hal itu dapat dilihat dari kualitas Rencana Pelaksanaan Pembelajaran (RPP) pada siklus I dan siklus II dimana pada siklus I kualitas Rencana Pelaksanaan Pembelajaran (RPP) menunjukkan nilai dengan kategor Baik. Kemudian pada siklus II kualitas Rencana Pelaksanaan Pembelajaran (RPP) menunjukkan peningkatan nilai yang signifikan menjadi Sangat Baik.

Penggunaan model Cooperative Learning tipe Examples Non Examples mampu dan dapat meningkatkan pemahaman konsep siswa pada materi keragaman suku bangsa dan budaya di Indonesia di kelas V SDN Karang Mulya II.

\section{DAFTAR PUSTAKA}

Joyce, Bruce. Weil, Marsha. Calhoun, Emily. 2009. Model Of Teaching: Model-model Pengajaran. Bandung :Pustaka Belajar

Kilpatrick, J., Findell, B. 2001. Adding It Up: Helping Children Learn Mathematics. Washington, DC : National Academy Press.

Miftahul, Huda. 2013 Model-Model Pembelajaran. Yogyakarta : Pustaka pelajar.

Sapriya, dkk. 2007. Pengembangan pendidikan IPS Di Sd. Bandung : UPI Press.

Sapriya. 2009. Pendidikan IPS. Bandung : Rosda Karya.
Setyawan, Heru. 2011. "Pengertian dan Manfaat Metode Example non

Example"(http://www.konsistensi. com ) Diakses pada tanggal 18 september 2013 pk. 11.57. http://waspodots.blogspot.com/20 10/01/publikasi-disertasi.html 